\title{
Subsurface chlorophyll maximum in August-September 1985 in the CLIMAX area of the North Pacific
}

\author{
R. W. Eppley ${ }^{1}$, E. Swift ${ }^{2}$, D. G. Redalje ${ }^{3}$, M. R. Landry ${ }^{4}$, L. W. Haas ${ }^{5}$ \\ ${ }^{1}$ Institute of Marine Resources, A-018, Scripps Institution of Oceanography, University of California, San Diego, La Jolla, \\ California 92093, USA \\ ${ }^{2}$ Narragansett Marine Laboratory, University of Rhode Island, Kingston, Rhode Island 02881, USA \\ ${ }^{3}$ Center for Marine Science, University of Southern Mississippi, National Space Technology Laboratories, NSTL, \\ Mississippi 39529, USA \\ ${ }^{4}$ Department of Oceanography, WB-10, University of Washington, Seattle, Washington 98195, USA \\ ${ }^{5}$ Virginia Institute of Marine Science, College of William and Mary, Gloucester Point, Virginia 23062, USA
}

\begin{abstract}
The deep chlorophyll maximum (DCM) is a widespread feature in the subtropical gyre of the North Pacific. In mid-August 1985, chlorophyll concentration increased in the DCM, then declined over time at 95 to $110 \mathrm{~m}$ depth near $28^{\circ} \mathrm{N} 155^{\circ} \mathrm{W}$ During the higher chlorophyll period the DCM lay within the top of the nitracline. Later, as the chlorophyll concentration declined and the DCM deepened, following the 24.9 sigma-t surface, the maximum was above the nitracline. The DCM was also a maximum in abundance of autotrophic flagellates. Particulate nitrogen was retained over time in the euphotic zone, relative to particulate carbon and chlorophyll. Phytoplankton growth rate at 90 to $110 \mathrm{~m}$ depth averaged $0.11 \mathrm{~d}^{-1}$ and phytoplankton carbon was about $10 \mu \mathrm{g} \mathrm{l}^{-1}$, about $50 \%$ of the total particulate carbon.
\end{abstract}

\section{INTRODUCTION}

This is a report of observations on the deep chlorophyll maximum (DCM) region mid-August to early September, 1985 , at $28^{\circ} \mathrm{N} 155^{\circ} \mathrm{W}$ in the North Pacific during the PRPOOS program (Plankton Rate Processes in Oligotrophic Oceans) cruise. A deep subsurface chlorophyll maximum is a prominent biological feature of many oceanic regions (see Cullen 1982 for review). DCM's are thought to result from in situ growth of phytoplankton at low light levels near the base of the euphotic zone where growth is dependent both upon regenerated nutrients and on nitrate diffusing upward across the nutricline (Fasham et al. 1985). The DCM in the North Pacific is continuous across the ocean basin at depth above the nutricline (Venrick et al. 1972, Venrick 1979). The feature has been studied in considerable detail at the CLIMAX (SIO 1974) station, $28^{\circ} \mathrm{N}$ $155^{\circ} \mathrm{W}$, where it is found at about $100 \mathrm{~m}$ depth. Studies in the 1970's suggested it was neither a phytoplankton biomass (Beers et al. 1975, 1982) nor a primary production maximum. Apparently the elevated chlorophyll reflected a photoadaptive response of the phytoplank- ton, altering the chlorophyll/biomass ratio (Eppley et al. 1973, Kiefer et al. 1976). Since then the discovery of eucaryotic pico- and nanoplankton (Johnson \& Sieburth 1982) has permitted investigation of such organisms in the DCM. Small eucaryotic phytoplankton are numerically dominant forms in DCM's in both the Sargasso Sea (Glover et al. 1985) and the North Pacific (Furuya \& Marumo 1983). Even though the DCM is at or below the $1 \%$ light depth, about $10 \%$ of the primary production takes place within it (Venrick et al. 1972, Laws et al. 1987).

Physiological studies suggested the DCM at the CLIMAX station is dependent upon in situ, lightlimited growth. The lower portion of the euphotic zone, including the chlorophyll maximum, is important as a site of new production in this region based upon sediment trap observations (Knauer et al. 1984) and particle scavenging of ${ }^{234} \mathrm{Th}$ (Coale \& Bruland 1987). Venrick (1982) has identified 2 distinct associations of phytoplankton species at the CLIMAX station, separated by depth. The DCM is related to the transition between the 2 regions.

Cullen (1982) has proposed that the central subtropi- 
cal gyre waters represent an extreme oligotrophic situation, beyond that of the 'Typical Tropical Structure' (TTS) defined by Herbland \& Voituriez (1979). In the TTS regions primary production, chlorophyll concentration integrated over the depth of the water column, and the depth of the maxima in primary production, chlorophyll and nitrite are correlated with, and predictable from, the depth of the nitracline lying within the euphotic zone. Variability in the biological measurements (chlorophyll, productivity, zooplankton biomass) at the CLIMAX station is 2- to 3 -fold between cruises and stations, and even cruise means of these properties are uncorrelated (Hayward et al. 1983). Temporal and spatial changes related to nitracline depth have not been observed (Hayward 1987) as they have in TTS regions.

During the PRPOOS cruise the chlorophyll concentration in the DCM increased for a few days then declined as the layer deepened. This provided a new opportunity to gather related environmental data and to speculate on the dynamics of the DCM (the present observations being ancillary to the main work of the cruise; see Eppley 1982). The observations imply a small recharging of the surface layer nitrogen. Results seem to be consistent with a scenario as follows. The first response to nitrate input at the base of the euphotic zone is a chlorophyll increase in the DCM. This is followed by a relaxation of nitrate input and a decrease in chlorophyll in the DCM. Meanwhile the input nitrogen, no longer nitrate, is transferred throughout the euphotic zone as evidenced by an increase of particulate nitrogen and autotrophic flagellate populations. Transient increases in chlorophyll concentration in the DCM may signal recent inputs of new nutrients at the base of the euphotic zone.

\section{METHODS}

The RV 'Melville' arrived on station on 19 Aug 1985 at $28^{\circ} \mathrm{N} 155^{\circ} \mathrm{W}$. It then steamed slowly over the track shown in Fig. 1 until 4 Sep. Scientific work was organized in 3 time blocks of $6 \mathrm{~d}$ each. Within each $6 \mathrm{~d}$ period, $3 \mathrm{~d}$ were devoted to sediment trapping and in situ deployment of arrays of diffusion cultures. The second $3 \mathrm{~d}$ period emphasized in situ experiments in $500 \mathrm{l}$ plastic bags. Sampling for primary production experiments (Marra \& Heinemann in press), growth rate studies (Laws et al. 1987), and hydrography and particulate analysis (reported here) took place each day. Nights were devoted to studies of bioluminescence and to net tows for zooplankton (to be reported by others) and microzooplankton. Water samples for most of the present measurements were taken with a CTD rosette system, equipped with $30 \mathrm{l}$ PVC Niskin sampling bottles supplied by the PACODF (Physical and Chemical Oceanographic Data Facility) group at Scripps Institution of Oceanography. Water samples for rate measurements were taken with $30 \mathrm{l}$ GO-FLO botthes lowered on KEVLAR line and prepared according to the trace metal 'clean' methods of Fitzwater et al. (1982). PACODF also processed the CTD and autoanalyzer nutrient data after the cruise. Twenty-four CTD casts were completed using a 12-bottle rosette sampling system with a modified NBIS Mark 3 CTD. The CTD data were recorded at sea on audio tape. Check samples for salinity were run with each cast. Additional CTD (Seabird), submarine light (Li-Cor 190S, 4 pi sensor) and relative chlorophyll fluorescence (SeaMarTec fluorometer) profiles were taken with an independent instrument system provided by the University of Rhode Island. Surface irradiance was recorded on the ship at hourly intervals with a Li-Cor quantum sensor with cosine response.

Microzooplankton reported here were collected with an in situ pumped system with a flow of about $11 \mathrm{l}$ $\mathrm{min}^{-1}$, a component of the Seabird CTD array. Animals were captured with a $25 \mu \mathrm{m}$ mesh net. About $60 \mathrm{l}$ were pumped through the nets at each depth. The pumping rate was monitored with a flowmeter before and after each cast and the duration of pumping was recorded. The 'dead' volume between the pump and net was about 11 . Samples from the nets were preserved in $5 \%$ buffered formalin. The choice of preservative and the fact that the organisms passed through the pump before being captured in the net suggests that naked ciliates, presumed to be present in high numbers, were not observed when the samples were examined for enumeration with a Zeiss IM35 inverted microscope. Protoperidinia and other cells smaller than $20 \mu \mathrm{m}$ were

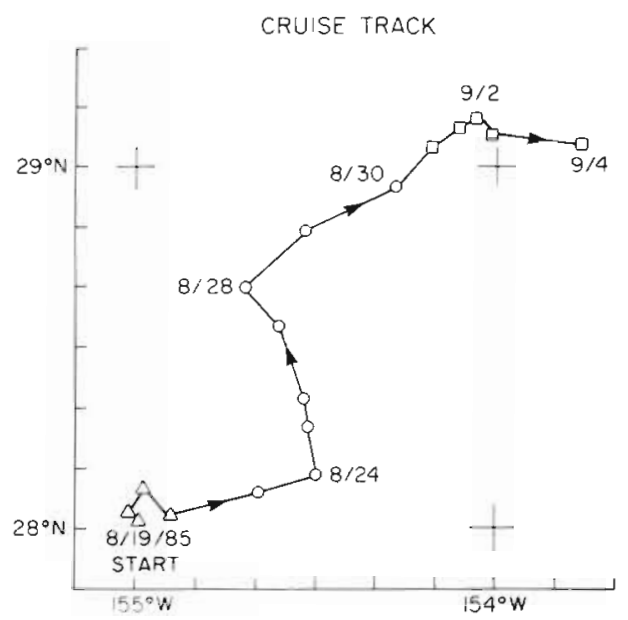

Fig. 1 Cruise track of the RV 'Melville' during Leg III of the Alcyone Expedition, PRPOOS cruise. Work was carried out in 3 series of 6 d each. Symbols indicate the different 6 d series. Work on 5 Sep was done enroute to the starting point 
collected, but are presumed to be under-represented in the samples

Slides for epifluorescence enumeration of pico- and nanoplankton population abundances were prepared following a modification of the proflavin technique originally proposed by Haas (1982). Freshly collected water samples of $25 \mathrm{ml}$ were stained for $5 \mathrm{~min}$ with $6.6 \mathrm{ppm}$ proflavin before being fixed with $0.5 \%$ glutaraldehyde and concentrated on a black $0.2 \mu \mathrm{m}$ pore size Nuclepore filter where they were stained for a further $5 \mathrm{~min}$ with DAPI at $8 \mathrm{ppm}$. Autotrophic and heterotrophic flagellates and bacteria and cyanobacteria were counted on shipboard under oil immersion $(1000 \times)$ using a Zeiss Standard microscope with mercury lamp and the appropriate filter sets. Only results for autotrophic flagellates are reported here. Population counts were generally coordinated with experimental studies rather than hydrographic work. Consequently, chlorophyll and population profiles were not often made from the same samples.

Water samples for particulate and nutrient analysis were collected with the rosette sampling system. Two sampling regimens were followed in each of the $6 \mathrm{~d}$ work cycles, one with casts to $140 \mathrm{~m}$ ('shallow' casts), the other to $1000 \mathrm{~m}$ ('deep' casts). Shallow series casts were done mornings and evenings for $3 \mathrm{~d}$ at depths of $0,10,20,30,50,70,90,100,110,120,130$, and $140 \mathrm{~m}$. This was modified on occasion by adding 15, 150 and $200 \mathrm{~m}$ and deleting 10,20 and $100 \mathrm{~m}$ samples. The deep casts were done once per day at depths of 1,10 , $20,30,50,70,90,100,110,120,130$, and $140 \mathrm{~m}$ in one cast and 150, 175, 200, 225, 250, 300, 350, 400, 500, 600, 700,800 , and $1000 \mathrm{~m}$ in a second cast. Overall, the sampling consisted of $3 \mathrm{~d}$ of shallow casts followed by $3 \mathrm{~d}$ of deep casts with the sequence repeated 3 times over an $18 \mathrm{~d}$ period.

On each cast water samples were filtered using HA Millipore membrane filters $10.45 \mu \mathrm{m}$ nominal mesh size) for chlorophyll measurements. The filters were extracted for $24 \mathrm{~h}$ in $90 \%$ acetone in the cold and dark. Chlorophyll fluorescence was determined, before and after acidification, with a Turner model 111 fluorometer, and chlorophyll calculated according to Holm-Hansen et al. (1965). Water samples for particulate carbon and nitrogen measurement (Sharp 1974) were filtered using pre-combusted Whatman GF/F glass fiber filters. Nitrate, phosphate and silicic acid were measured with an autoanalyzer. Nitrate was also measured at submicromolar concentrations using a chemiluminescent analyzer (Garside 1982).

Phytoplankton specific growth rate and biomass as carbon were determined by assessing the incorporation over $24 \mathrm{~h}$ of ${ }^{14} \mathrm{C}$ into chlorophyll (Redalje \& Laws 1981). Samples from the depth of the DCM were taken from 0400 to $0600 \mathrm{~h}$ on 3 occasions and deployed at dawn for this purpose. Two were incubated on deck in incubators simulating the irradiance and temperature of the $1 \%$ light depth, the third was incubated in situ. Chlorophyll was isolated and determined by HPLC methods for these samples (Mantoura \& Llewellyn 1983)

\section{RESULTS}

\section{Chlorophyll distribution}

The time-depth section of chlorophyll $a$ is shown in Fig. 2. Surface chlorophyll reached $0.2 \mu \mathrm{g} \mathrm{l^{-1 }}$ only twice, on 20 Aug and again on 25-26 Aug. The 25 Aug increase was associated with salinity change (Fig. 3). Chlorophyll concentrations in the DCM reached highs, $>0.3$ to $0.4 \mu \mathrm{g} \mathrm{I}^{-1}$ on the same days and the highs

AUGUST-SEPTEMBER 1985

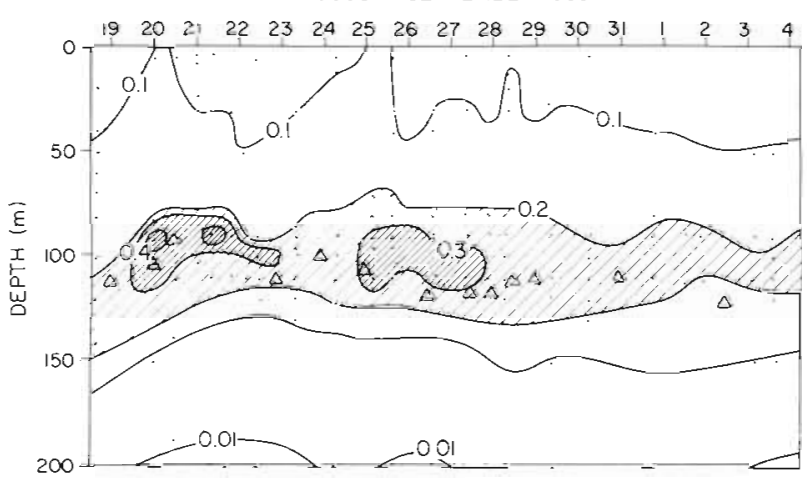

Fig. 2. Chlorophyll a section during the PRPOOS cruise. Maximum chlorophyll concentrations of $0.4 \mu \mathrm{g} \mathrm{l}^{-1}$ were noted on 20-21 Aug. Contours are based on bottle cast data. $(\Delta)$ Position of the maximum chlorophyll fluorescence determined in continuous profiles

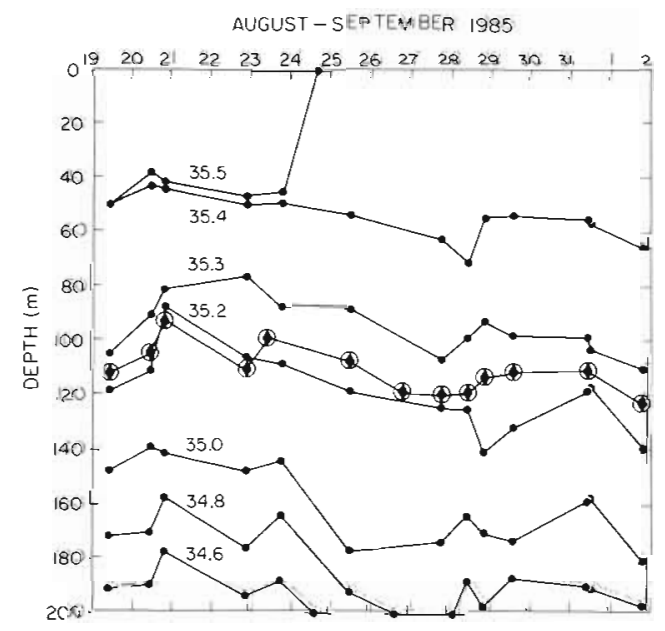

Fig. 3. Salinity section also showing the depth of the chlorophyll fluorescence maximum (†) 
persisted for 2 to $3 \mathrm{~d}$ (Fig. 2). Sampling the DCM with water bottles, as in Fig. 2, is a chancy affair and the reported chlorophyll concentrations do not necessarily represent the absolute maximum value in any profile. Fortunately, the continuous profiles of relative chlorophyll fluorescence corroborated the changes to be discussed.

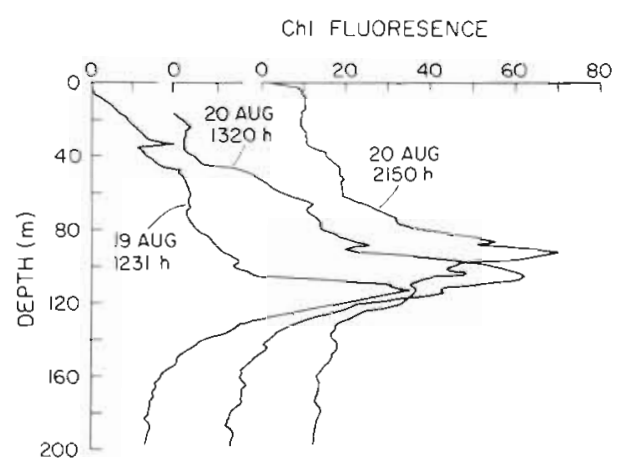

Fig. 4. The first 3 chlorophyll fluorescence profiles showing a shoaling of the depth of maximum fluorescence from 19 to 20 Aug

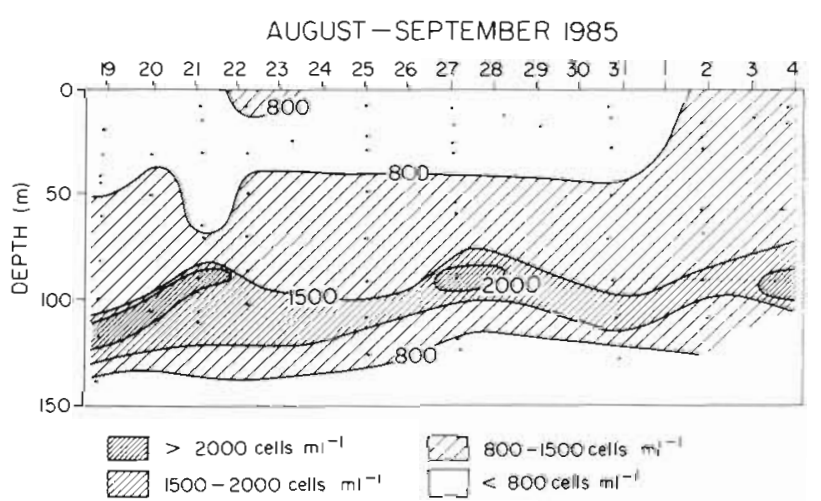

Fig. 5. Time dependence of autotrophic flagellate abundance profiles during the PRPOOS cruise

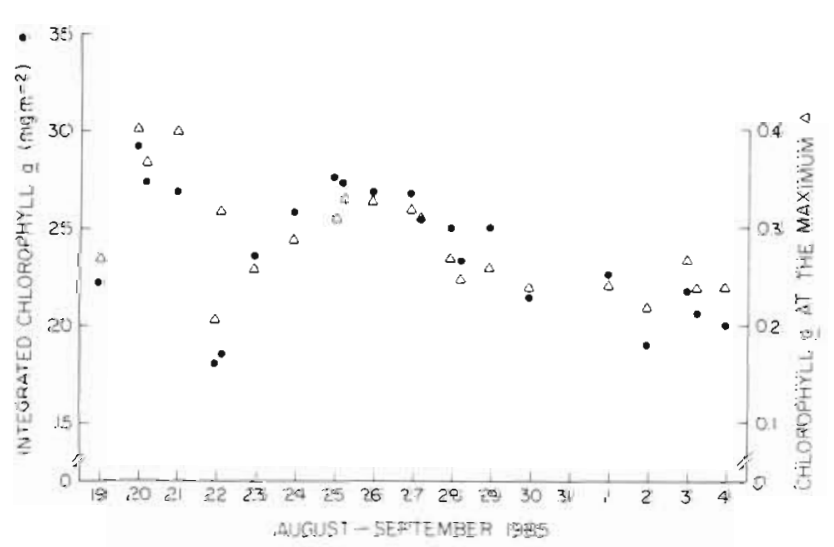

Fig. 6. Depth-integrated chlorophyll a, o to $150 \mathrm{~m}\left(\bullet_{\text {; }}\right.$ left ordinate) and concentration of chlorophyll $a$ at the chlorophyll maximum, $\mu \mathrm{gl}^{-1}$ ( $\Delta_{\text {; right }}$ ordinate)
The $0.2 \mu \mathrm{g} \mathrm{l}^{-1}$ chlorophyll isopleths suggest a shoaling of the DCM from 19 to $21 \mathrm{Aug}$. This shoaling is also seen in the depth of the fluorescence maximum in the first 3 lowerings of the fluorometer (Figs. 3 and 4). In addition, the 2 daytime profiles (Fig. 4) show increasing magnitude of fluorescence, consistent with the increased concentrations observed in the bottle samples. Diel periodicity in chlorophyll fluorescence complicates such comparisons and may explain the lower fluorescence peak at $2150 \mathrm{~h}$.

Peak abundances of autotrophic flagellates were observed in the DCM at the same time as the chlorophyll increases (Fig. 5). Autotrophic flagellates numerically dominated the DCM where they reached concentrations of $2 \times 10^{6} \mathrm{l}^{-1}$. A section of chlorophyllcontaining, autotrophic flagellates (Fig. 5) resembles the distribution of chlorophyll (Fig. 2). Highest populations were recorded in the periods 19 to $22 \mathrm{Aug}$ and again on 27 Aug in the DCM. A third increase is implied by the sample of 4 Sep. The counts of autotrophic flagellates also increased in the upper $30 \mathrm{~m}$ on 2 to 4 Sep during the last days of sampling (Fig. 5).

The chlorophyll concentration at the DCM varied by a factor of 2 during the cruise (Figs. 2 and 6). The highest chlorophyll concentrations, $0.4 \mu \mathrm{g} \mathrm{l^{-1 }}$, are higher than previously noted at the CLIMAX station (Hayward et al. 1983, Venrick et al. in press [b]). Earlier studies used GF/C glass fiber filters. These are somewhat coarser than the HA membrane filters we used which may partly account for differences in chlorophyll between this cruise and earlier ones. The relative bias between GF/C and the finer GF/F glass fiber filters is about $15 \%$ in low-chlorophyll waters (Venrick \& Hayward 1984) and may be similar for comparisons between GF/C and HA chlorophyll retention. The higher densities of flagellates observed relative to Beers et al. (1982) likely reflect recent improvements in preservation and epifluorescent counting techniques. Depthintegrated chlorophyll, 0 to $150 \mathrm{~m}$, was correlated with the chlorophyll concentration at the DCM (Fig. 6).

Temperature at the depth of the DCM increased during the cruise, from about 19.8 to $20.0^{\circ} \mathrm{C}$ on 19 to 21 Aug to a maximum of $20.6^{\circ} \mathrm{C}$ on 29 Aug (data not shown). Correspondingly salinity at the DCM changed from about 35.2 to 35.25 ppt. (Fig. 3).

\section{Hydrographic setting}

The salinity section produced by the Seabird CTD (Fig. 3) shows rising isopleths from 19 to $21 \mathrm{Aug}$, then a deepening that persisted until 28 Aug. A section of density, produced jointly by the 2 CTDs, is shown in Fig. 7. The DCM was found near the 24.9 isopleth of sigma-t. The isobars of Fig. 7 appear nearly parallel. 
The salinity section (Fig. 3) suggests compression of the 35.2 to $35.3 \mathrm{ppt}$ isopleths on $21 \mathrm{Aug}$, expansion on 23 Aug, compression again 28 Aug followed by expansion on 29 Aug and compression on 1 Sep. The density section suggests a similar sequence of compression and expansion between the 24.8 to 25.0 isobars (Fig. 7). Such changes can alter the shape of chlorophyll fluorescence profiles (Dickey et al. 1986).

Trade winds were light during the cruise (Fig. 8). Winds in excess of $8 \mathrm{~m} \mathrm{~s}^{-1}$ blew for several hours from 19 to 21 Aug (the strongest winds of the cruise), inter-

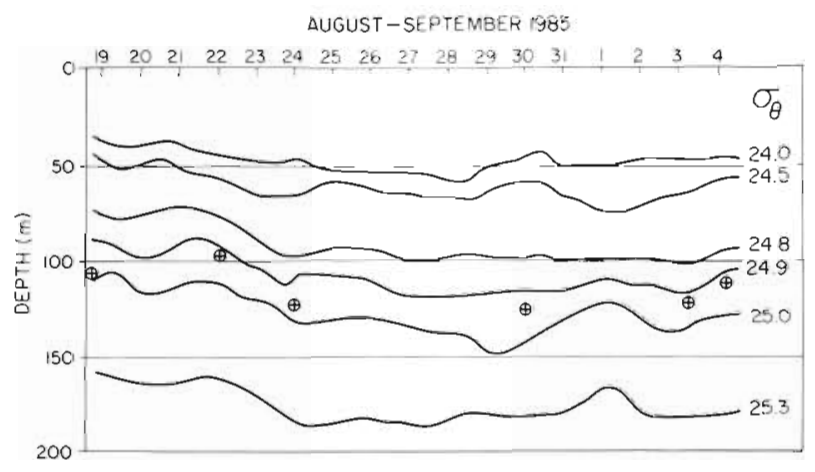

Fig. 7. Section of sigma-t, also showing depth of the top of the nitracline $(\oplus)$

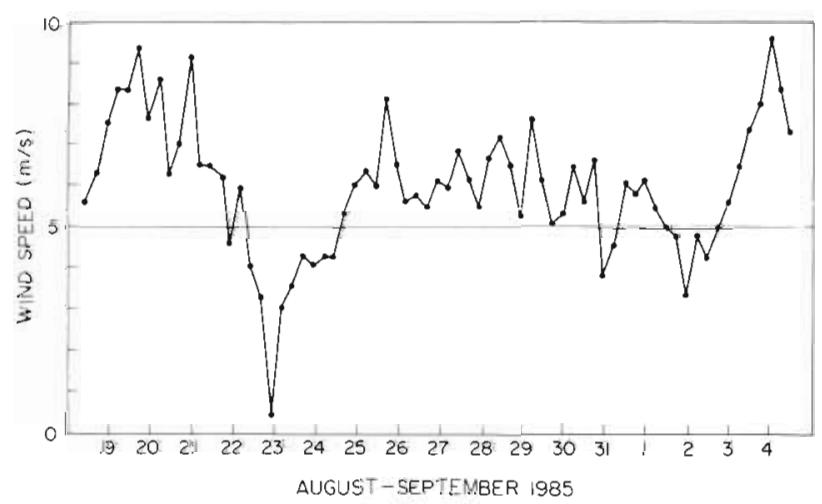

Fig. 8. Wind speed, 6 h averages, during the study

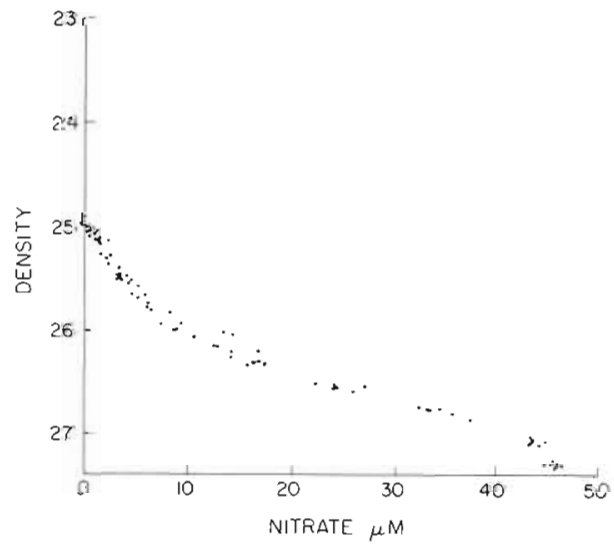

Fig. 9. Nitrate vs sigma-t based on autoanalyzer nitrate measurements mittently from 26 to 29 Aug, and for several hours on 4 Sep. Daily insolation was fairly uniform, averaging $44.6 \mathrm{E} \mathrm{m}^{-2} \mathrm{~d}^{-1}$ with standard deviation 5.2. Most days were partly cloudy with occasional rain.

\section{Nitrate distribution}

Nitrate concentration was correlated with temperature and density as in previous studies (Fig. 9). The graph implies 2 segments with different nitrate/sigma- $t$ relations. The change in slope took place at 26.0 sigmat and $9 \mu \mathrm{M}$ nitrate. Nitrate went to analytical zero (i.e. 0.1 to $0.2 \mu \mathrm{M}$ ) at sigma-t approximately 25.0. The slope of the nitrate-depth relation (not shown) also changed with depth, from $0.04 \mathrm{mmol} \mathrm{m}^{-4}$ between about 110 and $350 \mathrm{~m}$, to $0.056 \mathrm{mmol} \mathrm{m}^{-4}$ between 350 and $1000 \mathrm{~m}$ depth. The DCM (at temperatures 19.8 to $20.6^{\circ} \mathrm{C}$ ) rested directly above the nitracline, based upon the autoanalyzer nitrate measurements.

The chemiluminescent nitrate values were much less than $100 \mathrm{nM}$ above the nitracline, and it was easy to resolve the top of the nitracline as the depth where the nitrate concentration reached $100 \mathrm{nM}$ as defined by Le Bouteiller (1986). The nanomolar nitrate data from the 4 depth profiles in the period 18 to 30 Aug suggest the DCM was within the nitracline in that period (Fig. 10). Three subsequent profiles showed the DCM above the nitracline.

The position of the nitracline (chemiluminescent nitratc) differed between the bottle casts with such data. On 19 Aug, it was at $108 \mathrm{~m}$. It shoaled to $95 \mathrm{~m}$ on 22 Aug, and then deepened to $110 \mathrm{~m}$ on $24 \mathrm{Aug}$. In later casts the nitracline was found between 110 and $125 \mathrm{~m}$. Nitracline depths were 10 to $27 \mathrm{~m}$ deeper when defined by the autoanalyzer data (as the first increase above the blank). Those depths were 105 to $152 \mathrm{~m}$. The concentration gradients of phosphate and silicic acid began either at the same depth or a few meters deeper than the top of the nitracline, based on the autoanalyzer data.

\section{Submarine light}

The diffuse attenuation coefficient for photosynthetically active irradiance changed with depth. Besides the initial loss of longer wavelengths in the upper $20 \mathrm{~m}$, there was curvature as the relatively clear water in the depth range 20 to $75 \mathrm{~m}$ gave way to less clear water toward the chlorophyll maximum (Fig. 11). The increase in the diffuse attenuation coefficient $(\mathrm{K})$ of the lower water is associated with higher chlorophyll but lower POC and PN. We think of the North Pacific central gyre as extremely oligotrophic, yet the $1 \%$ light 
depth averaged only $88 \mathrm{~m}$ during this cruise (Table 1 ). The mean diffuse attenuation coefficient for photosynthetically active (PAR) scalar irradiance averaged 0.042 (Table 1). The Jerlov water type was $1 \mathrm{~B}$. This agrees with the historical values reported by Simonot \& Le Treut (1986).

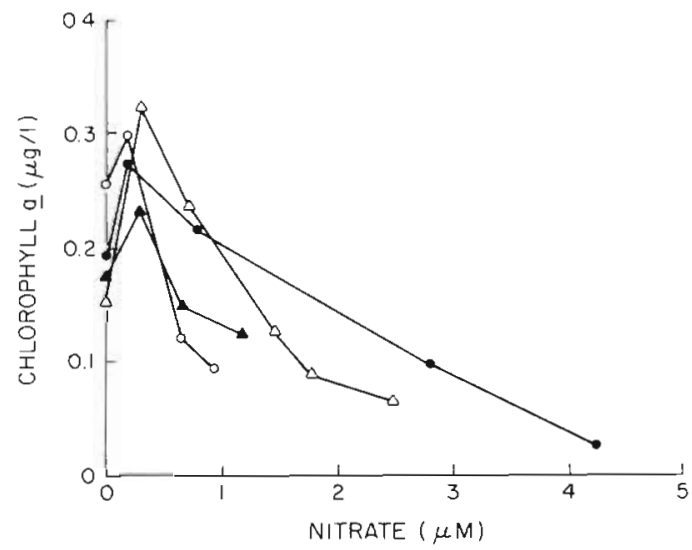

Fig. 10. Four depth profiles of chlorophyll and nitrate (chemiluminescent method) in which the chlorophyll maximum was found within the nitracline. Symbols represent profiles on different days: (๑) $18 \mathrm{Aug} ;(\Delta) 22 \mathrm{Aug}$ ( () $24 \mathrm{Aug}$;

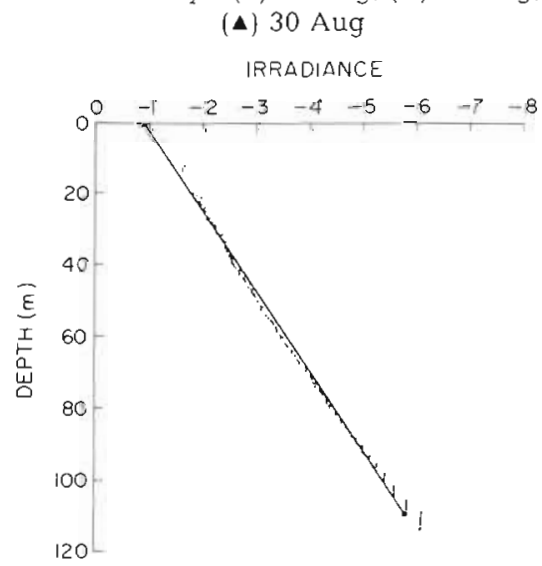

Fig. 11. Depth profile of submarine light (natural log scale), 1320 h, 25 Aug. Departure of points from the regression line emphasizes the non-linearity

\section{Phytoplankton growth in the DCM}

Water samples from the chlorophyll maximum were collected by trace metal 'clean' methods and incubated on 3 occasions to assess phytoplankton growth rate and biomass carbon using the chlorophyll labeling technique (Table 2). The average growth rate was $0.11 \mathrm{~d}^{-1}$ while phytoplankton carbon at the beginning of the incubation was 8.8 to $12 \mu \mathrm{g} \mathrm{l}^{-1}$. The phytoplankton carbon comprised about half of the POC. The 21 and 26 Aug samples (Table 2) were taken just below the $1 \%$ light depth and were incubated on deck in a $1 \%$ light incubator. The 2 Sep sample was taken at $110 \mathrm{~m}$, the expected depth of the DCM, and was incubated in situ at $110 \mathrm{~m}$.

\section{Particulate nitrogen in the euphotic zone}

Sixteen casts were made with sampling at 30 and $110 \mathrm{~m}$ depth. Eleven of these casts also included samples from $70 \mathrm{~m}$. Chlorophyll, POC and PN were measured on the samples. Linear regression of concentrations on time indicated no long-term temporal trend in POC or chlorophyll at these depths, while there were significant increases in $\mathrm{PN}$ at 30 and $110 \mathrm{~m}$ and decreases in the POC/PN ratio over time at all 3 depths (Table 3). This result contrasts with the earlier claim of chlorophyll decline over time (and see the last 2 rows of Table 3) and implies that the limited-depth sampling was not fully representative of the euphotic zone. The actual changes were probably greater than the regressions of Table 3 suggest.

On 5 other occasions multiple-depth sampling allowed estimates of depth integrated POC, PN and chlorophyll in the euphotic zone. PN increased over time in these samples also, both in absolute content (from 450 to $670 \mathrm{mg} \mathrm{m}^{-2}$ ) and relative to POC and chlorophyll. The PN/chlorophyll ratio increased from 21 to $30(\mathrm{~g} / \mathrm{g})$.

Table 1. Optical data comparing the oligotrophic Sargasso Sea to the 'PRPOOS' stations in the North Pacific central gyre. Two August cruises are compared: the 'CLIMAX' station, ca $28^{\circ} \mathrm{N}, 155^{\circ} \mathrm{W}$, and the mean of 3 stations in the western Sargasso Sea ('BIOLUM' cruise) in the area bounded by 25 to $33^{\circ} \mathrm{N}, 65$ to $69^{\circ} \mathrm{W}$

\begin{tabular}{lcc}
\hline & PRPOOS & BIOLUM \\
\hline Depth of $10 \%$ of surface scalar irradiance & $34 \mathrm{~m}$ & $51 \mathrm{~m}$ \\
Depth of $1 \%$ of surface scalar irradiance & (SE mean $=1 \mathrm{~m}, \mathrm{n}=9)$ & (SE mean $=2 \mathrm{~m}, \mathrm{n}=6)$ \\
& $88 \mathrm{~m}$ & $113 \mathrm{~m}$ \\
Mean diffuse attenuation coefficient for PAR & (SE mean $=2 \mathrm{~m}, \mathrm{n}=8)$ & (SE mean $=3 \mathrm{~m}, \mathrm{n}=6)$ \\
& (SE mean $=0.001, \mathrm{n}=6)$ & -0.037
\end{tabular}




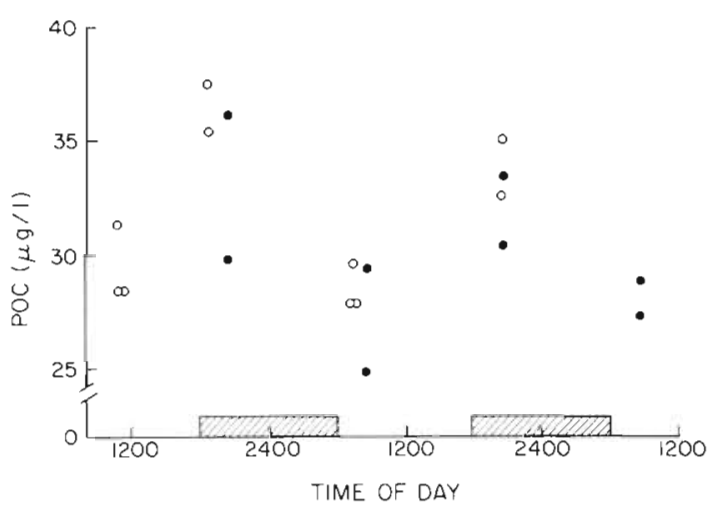

Fig. 12. Particulate organic carbon (POC) at $30 \mathrm{~m}$ depth vs time of day. (O) 20-21 Aug; (-26-28 Aug

\section{Change over depth}

The expected changes with depth in chlorophyll, $P O C$ and PN were seen in the samples from 30,70 and $110 \mathrm{~m}$, as shown, for example, in the averages and the intercepts of the regression equations of Table 3. Particulate matter was enriched in chlorophyll and nitrogen, relative to carbon, with increasing depth in the euphotic zone.

\section{Diel changes}

Diel studies of POC and PN were done on 3 occasions, following Postma \& Rommets (1979). Differences

Table 2. Primary production (Prod.), specific growth rate of chlorophyll-containing phytoplankton ( $\mu$ ), phytoplankton biomass as carbon $(\mathrm{Cp})$ and chlorophyll a (chl) at the time of sampling, and biomass carbon/chlorophyll a ratio at the depth of the deep chlorophyll maximum

\begin{tabular}{|ccccccc|}
\hline Date & $\begin{array}{c}\text { Sample depth } \\
(\mathrm{m})\end{array}$ & $\begin{array}{c}\text { Prod. } \\
\left.(\mu \mathrm{g} \mathrm{C})^{-1} \mathrm{~d}^{-1}\right)\end{array}$ & $\begin{array}{c}\mu \\
\left(\mathrm{d}^{-1}\right)\end{array}$ & $\begin{array}{c}\mathrm{Cp} \\
\left.(\mu \mathrm{g} \mathrm{l})^{-1}\right)\end{array}$ & $\begin{array}{c}\mathrm{chl} \\
\left.(\mu \mathrm{g} \mathrm{l})^{-1}\right)\end{array}$ \\
\hline 21 Aug & 100 & 1.03 & 0.09 & 11.75 & 0.13 & 89 \\
2 Aug & 90 & 1.06 & 0.10 & 10.05 & 0.23 & 43 \\
2 Sep & 110 & 1.42 & 0.15 & 8.84 & 0.16 & 57 \\
\hline
\end{tabular}

Table 3. Temporal change in POC, PN and chlorophyll a. Average values, slopes and intercepts of linear regression equations of

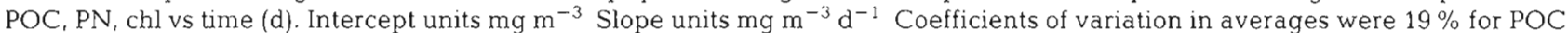
and PN, $13 \%$ for POC/PN, $18 \%$ for chlorophyll per $\mathrm{m}^{3}$ and $12 \%$ for chlorophyll per $\mathrm{m}^{2}$

\begin{tabular}{|c|c|c|c|c|c|}
\hline Depth $(\mathrm{m})$ & $\begin{array}{c}\text { No. of } \\
\text { measurements }\end{array}$ & Average & Slope & Intercept & $r$ \\
\hline \multicolumn{6}{|c|}{$\mathrm{POC}$} \\
\hline 30 & 39 & 30.6 & -0.027 & 30.8 & NS \\
\hline 70 & 28 & 27.3 & +0.097 & 26.3 & NS \\
\hline 110 & 40 & 20.8 & -0.086 & 21.5 & NS \\
\hline \multicolumn{6}{|c|}{ PN } \\
\hline 30 & 41 & 4.49 & 0.055 & 4.08 & $0.46, \mathrm{p}<0.01$ \\
\hline 70 & 28 & 4.67 & 0.063 & 4.02 & $0.35, p>0.05$ \\
\hline 110 & 40 & 3.61 & 0.039 & 3.36 & $0.37, p<0.05$ \\
\hline \multicolumn{6}{|c|}{$\mathrm{POC} / \mathrm{PN}$} \\
\hline 30 & 33 & 7.93 & -0.086 & 8.54 & $-0.64, p<0.01$ \\
\hline 70 & 28 & 6.88 & -0.080 & 7.72 & $-0.42, \mathrm{p}<0.05$ \\
\hline 110 & 35 & 6.71 & -0.127 & 7.70 & $-0.59, p<0.01$ \\
\hline \multicolumn{6}{|c|}{ chl } \\
\hline 30 & 28 & 0.107 & -0.0001 & 0.108 & NS \\
\hline 70 & 22 & 0.165 & -0.0006 & 0.170 & NS \\
\hline 110 & 21 & 0.255 & -0.0041 & 0.287 & NS \\
\hline At chl max & 23 & 0.266 & -0.0058 & 0.336 & $-0.55, p<0.01$ \\
\hline $\begin{array}{l}\text { Integrated } \\
(0 \text { to } 150 \mathrm{~m})\end{array}$ & 21 & $23.44^{\circ}$ & $-0.302^{\circ}$ & $26.72^{\circ}$ & $-0.42, p \sim 0.05$ \\
\hline $\begin{array}{l}\text { NS: not signif } \\
\text { Units } m g m^{-2}\end{array}$ & e and intercept & $m^{-2} d^{-1}$ & & & \\
\hline
\end{tabular}


between morning and evening samples were seen in 2 of these studies among the $30 \mathrm{~m}$ samples (Fig. 12), but not among the $70 \mathrm{~m}$ or $110 \mathrm{~m}$ samples. The daily amplitude in POC at $30 \mathrm{~m}$ was in the range 5 to $10 \mu \mathrm{g}$ $1^{-1}$. The sets of points (duplicates or triplicates) are subsamples from the same water sampling bottle, not independent samples. Replication was poor for the 26-28 Aug samples, better for the 20-21 Aug samples. The daytime increases in POC at $30 \mathrm{~m}$ establish a coarse lower limit for primary production of 5 to $10 \mu \mathrm{g}$ $\mathrm{l}^{-1} \mathrm{~d}^{-1}$ with a corresponding night-time loss. The rate based upon radiocarbon primary production measure-

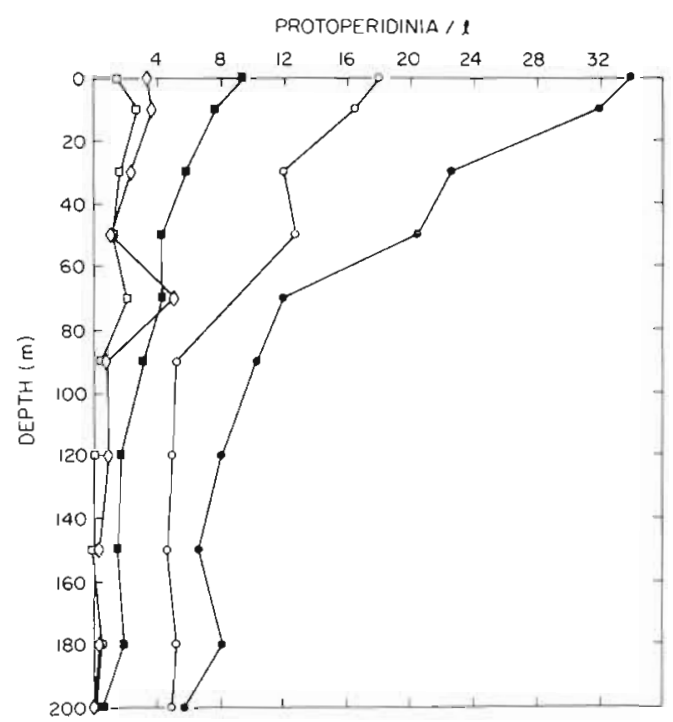

Fig. 13. Depth profile of Protoperidinia concentrations, 27-28 Aug. (•) Totals; (O) $<20 \mu \mathrm{m}$ diameter; (অ) 21 to $30 \mu \mathrm{m}$ diameter; (0) 31 to $40 \mu \mathrm{m}$ diameter; ( $(\square)>40 \mu \mathrm{m}$ diameter

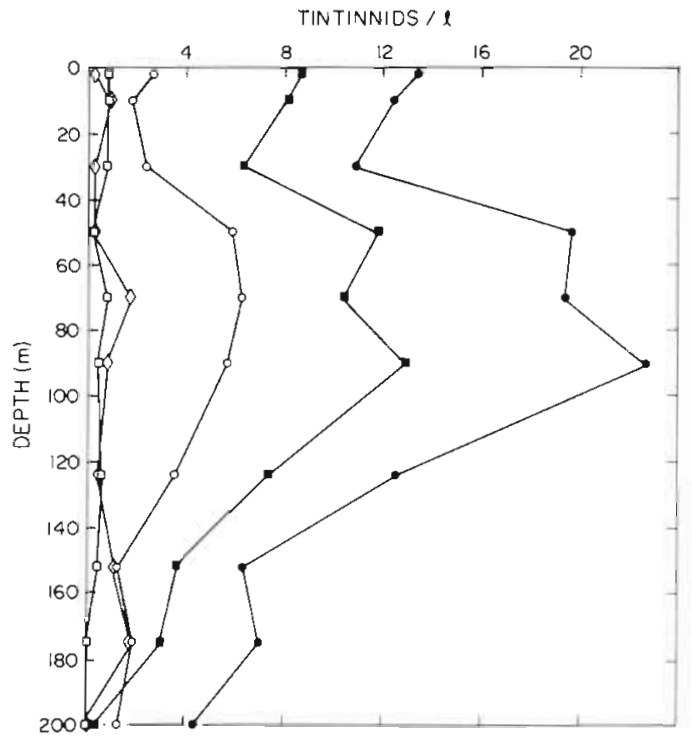

Fig. 14. Depth profile of tintinnids of different oral diameter,

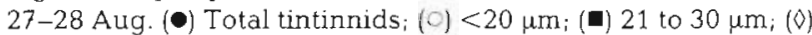
31 to $40 \mu \mathrm{m} ;(\square)>40 \mu \mathrm{m}$ ments was also in the range 5 to $7 \mu \mathrm{g} \mathrm{Cl}^{-1}$ at $30 \mathrm{~m}$ depth (Marra \& Heinemann in press). The diel changes in POC are of the same magnitude as the differences observed over time in weeks (Table 3). Neither chlorophyll, PN nor, surprisingly, the ratio POC/PN showed the diel changes.

\section{Distribution of grazing microzooplankton}

Microzooplankton known to ingest pico- and nanoplankton were enumerated in 2 vertical profiles taken during the nights of 21-22 and 27-28 Aug. The times of sampling corresponded to times of maximum concentration of chlorophyll in the DCM (Figs. 2 and 6). Crustacean nauplii, tintinnids and Protoperidinia were found at similar abundance at the DCM on both occasions. Euphotic zone abundances, however, were higher on 27-28 Aug than earlier.

Vertical profiles of heterotrophic dinoflagellates (Fig. 13) were dominated by the non-photosynthetic forms of Protoperidinium. These showed a near-surface peak on both dates. The smallest size-class had a second peak near the depth of the DCM on the night of 21-22 Aug, but not on the later sampling. Use of $25 \mu \mathrm{m}$ mesh nets means we have underestimated the number of small dinoflagellates. Thenon-photosynthetic dinoflagellates in the genera Podolampus and Oxytoxum had a similar vertical distribution (data not shown).

Vertical profiles of tintinnids are shown in Fig. 14, sorted according to the size of the oral diameter of the tintinnids. They were sorted in this manner because the size of food taken by tintinnids is thought to be related to the oral diameter. Tintinnid populations in all size classes showed some increase at the depth of the DCM on 21-22 Aug. A few consistent vertical patterns appeared when tintinnids were sorted by genus rather than by size (Fig. 15). Rhabdonella and Undella showed peaks above the DCM while Proplectella had a

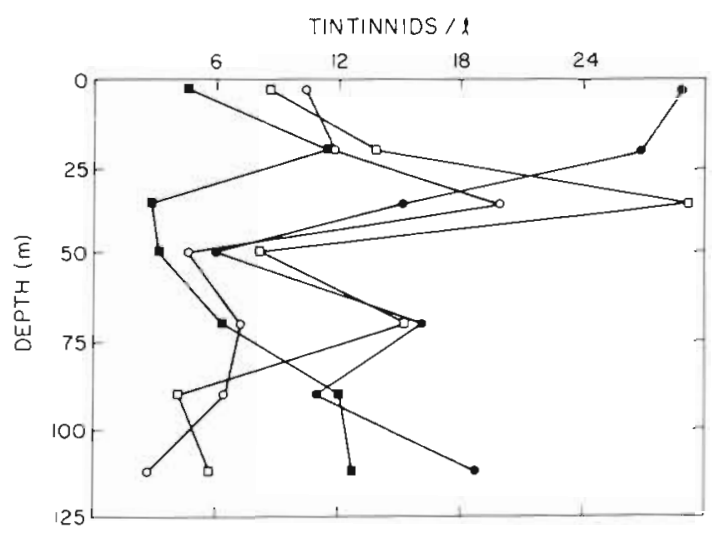

Fig. 15. Abundance of tintinnids, by genus, 21-22 Aug. ( Ascampbelliella; (O) Rhabdonella; ( $\square$ ) Undella; (-) Proplectella 
population maximum just above the peak in chlorophyll fluorescence.

Crustacean nauplii were found associated with the DCM (Fig. 16). Foraminifera and radiolarians did not show distinct peaks in our samples.

\section{DISCUSSION}

\section{Chlorophyll distribution}

The range and depth distributions of chlorophyll concentration observed in this cruise are similar to those observed on earlier cruises to the CLIMAX area, once corrections are made for the finer filters used here (Venrick \& Hayward 1984, Venrick et al. in press [a], [b]). Vertical distribution of chlorophyll was determined on the preceding leg of this expedition, using $\mathrm{GF} / \mathrm{C}$ filters. Maximum concentrations, observed on $29 \mathrm{Jul} 1985$ at $28^{\circ} \mathrm{N} 158^{\circ} \mathrm{W}$, were 0.19 to $0.21 \mu \mathrm{g} \mathrm{l}^{-1}$ at 95 to $115 \mathrm{~m}$ depth (T. Hayward, Scripps Institution of Oceanography, pers. comm.). Similar changes of chlorophyll concentration, on a time scale of days, have been reported also by Dandonneau \& Lamasson (1987) for the DCM in the tropical South Pacific at $15^{\circ} \mathrm{S}$ $173^{\circ} \mathrm{W}$. The magnitude of the changes occurring over a few days at the CLIMAX station is similar to the decadal trends reported by Venrick et al. (in press [b]). Mean values in the 1980 's are about twice those of the early 1970 's.

Maximum chlorophyll concentration was found at 95 to $120 \mathrm{~m}$ depth (Figs. 2 and 3). Within the resolution of the bottle casts, the DCM was coincident with peaks in

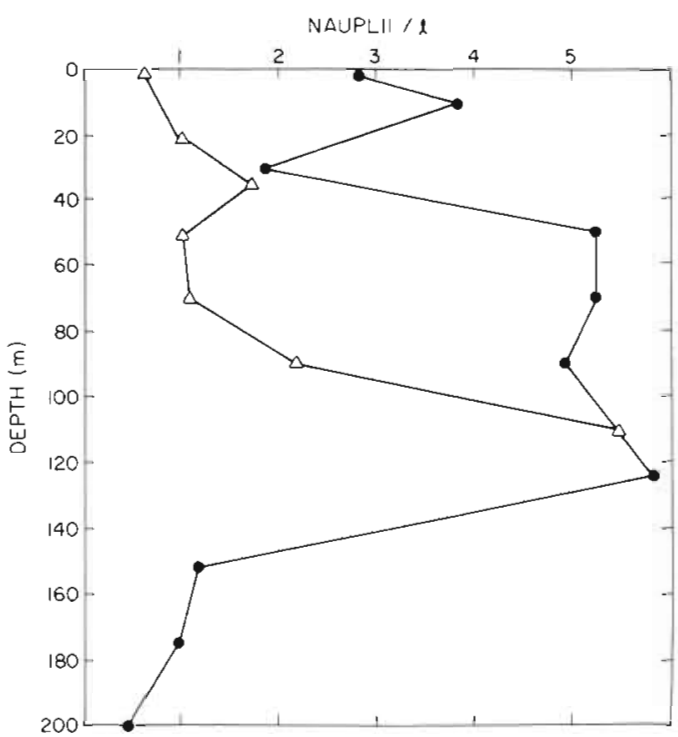

Fig. 16. Crustacean nauplii observed in 2 sampling periods,

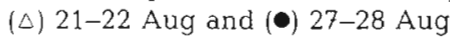

populations of autotrophic flagellates (Fig. 5). The depth of the DCM tracked the 24.8 to 24.9 sigma-t isobars (Fig. 7). The autotrophs of DCM's may generally include ultraphytoplankton containing chlorophyll $b$, based upon taxonomic observations (Furuya \& Marumo 1983) and pigment analysis (Gieskes \& Kraay 1986).

\section{Chlorophyll and chlorophyll fluorescence maxima}

Changes in the depth of in situ fluorescence maxima (Figs. 3 and 4) agreed with the motions postulated for the DCM from the bottle cast chlorophyll data. The fluorescence maximum was often a few meters deeper, however, than the peak in chlorophyll from the bottle casts. These independent observations were several hours apart which may account for much of the difference between them. The bottles were tripped at predetermined depths and the depth of the DCM was taken as one of those depths. This can lead to error in establishing the maximum concentration of chlorophyll and its vertical position, as well as in the depth integral of chlorophyll. An objective way of treating bottle cast chlorophyll profiles was developed by Dandonneau \& Lemasson (1987). It assumes an average relation between chlorophyll and density, modified by an error term and long-term trends. Their criteria appear to be valid from our data. We have not yet used the objective method since the chlorophyll fluorescence profiles provided independent support to the conclusions drawn from the bottle casts.

\section{Temporal change in the DCM}

The time variability in the depth of the DCM (Figs. 2 and 3) and in the integral of chlorophyll over depth (Fig. 6) are similar to the observations of Dandonneau \& Lemasson (1987, their Fig. 6). The records are about the same length (about 30 d) and both show 3 highs and 2 lows, suggesting changes with periods about $10 \mathrm{~d}$. Both records also show increased winds during some, but not all, of the times of chlorophyll increase (Fig. 8). The last peak in wind of Fig. 8 took place without an increase in chlorophyll, although an increase in the density of autotrophic flagellates in the DCM was observed (Fig. 5). We believe, as suggested also by our French colleagues, that the chlorophyll increase is in response to, and follows, physical forcing. Both records begin with a high in depth-integrated chlorophyll resulting from antecedent forcing. In our case, the forcing is still apparent in the shoaling of the DCM and sigma-t surfaces. Vertical motions and breaking of internal waves were suggested as a source of variabil- 
ity in primary production (McGowan \& Hayward 1978, Dandonneau \& Lemasson 1987), and there is evidence of isopleth displacement in the salinity (Fig. 3) and sigma-t (Fig. 7) sections. Unfortunately, our observations were not frequent enough to resolve internal wave activity, unlike those of Fasham et al. (1985), Dickey et al. (1986) and Dandonneau \& Lemasson (1987).

The consequences of the increase in chlorophyll in the DCM include increase in the depth integral of chlorophyll (Fig. 6). Changes in the DCM have dominated water column changes in primary production in previous studies in the North Pacific (Bienfang et al. 1984) and North Atlantic (Glover et al. 1986). In the tropical South Pacific, however, increase in depth-integrated chlorophyll were due largely to chlorophyll increase above the DCM (Dandonneau \& Lemasson 1987).

\section{Possible mechanisms of intensification of the chlorophyll maximum}

The DCM has been described as a nutrient trap in that the phytoplankton of the DCM is capable of assimilating nutrients input from below, thereby preventing new nutrients from reaching the upper euphotic zone (Anderson 1969). Photosynthesis and phytoplankton growth at the base of the euphotic zone are almost surely limited not by nutrient input rate but by light, and the standing stock of phytoplankton may be modulated as well by grazing pressure (Jamart et al. 1977, 1979).

On particularly dark days growth may slow and the nitrate diffusing into the DCM from below may not be fully absorbed, passing into the overlying waters (Taylor et al. 1986). We did not see this, even with a nitrate method capable of measuring nanomolar concen-

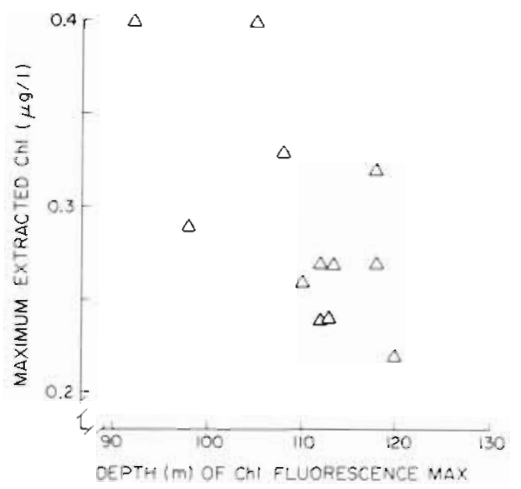

Fig. 17. Chlorophyll concentration in the DCM based on extracted samples from bottle casts vs depth of DCM based on the chlorophyll fluorescence maximum determined the same day trations, nor did Dandonneau \& Lemasson (1987). In our case, nitrate was detected within the DCM, but the time scale of sampling was inadequate to resolve any but multi-day phenomena. A leaky (to nitrate transport) DCM is one possible contributor to the maximum in oxygen supersaturation observed at about $70 \mathrm{~m}$ (Hayward 1987) which represents new production remote from the nitracline (Craig \& Hayward 1986, Coale \& Bruland 1987).

Three a posteriori hypotheses can be advanced to account for the observed changes in chlorophyll distribution during our cruise: (1) we crossed fronts with different properties in the water on either side (Fasham et al. 1985); (2) chlorophyll increased due to in situ growth; and (3) the apparent vertical motions and shape of the DCM resulted from interactions of internal waves such that the density range encompassing the DCM changed depth and was sometimes compressed or expanded, as observed by Dickey et al. (1986) and Dandonneau \& Lemasson (1987). Our observations are insufficient to resolve these alternatives, and none can be excluded. Nevertheless, the data are most complete with respect to the in situ growth suggestion and the evidence for a role of net in situ growth will be considered.

Phytoplankton growth in the DCM (Table 3 ) is slow compared to rates in the upper euphotic zone (Laws et al. 1987). Photosynthetic rates fit well with a model based upon light and quantum yield, implying lightregulated phytoplankton growth over the depth of the euphotic zone during this cruise (Marra \& Heinemann in press). However, the growth that does occur in the DCM is significant (Table 2); it supports a particle flux sufficient to alter the depth distribution of dissolved ${ }^{234} \mathrm{Th}$ (Coale \& Bruland 1987). The nitracline sometimes shoaled into the DCM (Fig. 10). The maximum chlorophyll concentration, from the bottle cast samples, varied with the depth of the chlorophyll fluorescence maximum determined independently (Fig. 17), as if the chlorophyll concentration responded to light with little or no time lag. The irradiance at the depth of the DCM is low enough to limit the growth rate of phytoplankton in culture and was usually less than $1 \%$ of surface light (as also reported by Glover et al. 1985, 1986, Murphy \& Haugen 1985, and others for DCM's elsewhere). The DCM shoaled during the first period of chlorophyll increase (Figs. 2 and 5).

These observations suggest that phytoplankton growth in the DCM is light-limited: shoaling of the DCM increases the light available to the phytoplankton, increasing the growth rate and, in time, the chlorophyll concentration in the DCM and the standing stock of phytoplankton. A chief weakness of the argument is that growth rate must increase substantially, without an increase in grazing pressure, in order to 
achieve the observed chlorophyll increases. We have no independent evidence that it did. We do have evidence that nitrate was present to support net biomass increase (Fig. 10).

\section{Particulate carbon and nitrogen}

Particulate carbon and nitrogen are not reported as often as chlorophyll and productivity observations, and therefore deserve some discussion. POC values in the upper $110 \mathrm{~m}$ were typically 20 to $30 \mathrm{mg} \mathrm{C} \mathrm{m}^{-3}$, similar to those reported by Ichikawa \& Nishizawa (1975) for August to October 1969 , between $25^{\circ}$ and $30^{\circ} \mathrm{N}$ on $115^{\circ} \mathrm{W}$ longitude. Gordon (1971) examined seasonal variation in particulate $\mathrm{C}$ and $\mathrm{N}$ at $22^{\circ} \mathrm{N} 158^{\circ} \mathrm{W}$ in 13 cruises between January 1969 and June 1970 , emphasizing depth profiles to $>4500 \mathrm{~m}$. From his Fig. 2, POC values in the surface waters averaged $27 \mathrm{mg} \mathrm{m}{ }^{-3}$ with $95 \%$ confidence limits of 23 to $31 \mathrm{mg}$ $\mathrm{m}^{-3}$. These, too, are very similar to present values. Sharp et al. (1980) found POC values of 19 to $25 \mathrm{mg}$ $\mathrm{C} \mathrm{m}^{-3}$ for the upper 60 to $70 \mathrm{~m}$ of the euphotic zone in June-July 1973 at the CLIMAX station. Gordon (1971) noted factor of 2 differences between cruises (and seasons; see also Sharp et al. 1980), comparable to the diel variation noted here. Different filters $(1.2 \mu \mathrm{m}$ silver filters were used by Gordon 1971, GF/C glass fiber filters by Ichikawa \& Nishizawa 1975 and by Sharp et al. 1980, GF/F glass fiber filters here) appear to have retained a similar concentration of POC throughout. Only some of the filters were fumed with $\mathrm{HCl}$ to remove calcium carbonate prior to analysis. Gordon (1971) found a $6 \%$ error in POC measurements from carbonates.

Particulate nitrogen concentrations in the present study were a little higher than the historical values. PN was about $4 \mathrm{mg} \mathrm{m}^{-3}$ in the upper $70 \mathrm{~m}$ in this study (Table 3), 2.5 to $2.9 \mathrm{mg} \mathrm{m}^{-3}$ in Sharp et al. (1980), about $3 \mathrm{mg} \mathrm{m}^{-3}$ in Ichikawa \& Nishizawa (1975), and about $3.5 \mathrm{mg} \mathrm{m}^{-3}$ in Gordon (1971, based upon the reported mean $\mathrm{C} / \mathrm{N}$ ratio of 7.5 by weight for the surface layer). As with POC, the seasonal variation in $\mathrm{PN}$ can be considerable (Gordon 1971, Sharp et al. 1980). The lack of measurable diel change in PN is consistent with the observation of continuous nitrogen assimilation by the plankton, not only during daylight but also at night, in the oligotrophic North Pacific (Laws et al. 1984). One might expect diel changes in the POC/PN ratio, analytical and sampling errors permitting, but this was not observed.

The POC and PN data are interesting with respect to our speculations on nitrogen dynamics. Both PN and autotrophic flagellates increased over time at $30 \mathrm{~m}$ depth, while POC and chlorophyll did not, and the
POC/PN ratio declined while the PN/chlorophyll ratio increased. (There is independent evidence of different behaviors of POC and PN in the sediment trap data, to be reported by J. Downs, University of Washington.) The observations are consistent with an increase in nitrogen in the euphotic zone over the course of the study. The nitrogen increase in the euphotic zone appears first as nitrate in the DCM and as DCM chlorophyll increase, then later as increased PN and autotrophic flagellates in the upper waters. If this scenario is correct, it implies a time sequence of changes in response to nutrient input at the base of the euphotic zone, with increases there only slowly translated to the upper euphotic zone. The observations also suggest an epipelagic ecosystem poised to retain nitrogen relative to carbon.

\section{Plankton biomass in the DCM}

Beers et al. (1982) reported microplankton biomass at the depth of the DCM from a cruise in August-September 1973 to the CLIMAX station. They reported total microplankton biomass of $9 \mu \mathrm{g} \mathrm{C}^{-1}$, standard

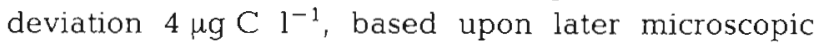
study of preserved samples. In those samples it was not possible to distinguish pigmented from non-pigmented organisms. As yet there are no comparable microscopical estimates of biomass from the PRPOOS study (L. Haas pers. comm.). The method based upon incorporation of ${ }^{14} \mathrm{C}$ into chlorophyll, however, suggested 8.8 to $12 \mu \mathrm{g} \mathrm{C} 1^{-1}$ biomass of chlorophyll-containing microorganisms (Table 3). There is a need to resolve the biomass problem with respect to the distribution of carbon among heterotrophs (including bacteria), heterotrophic dinoflagellates, and ciliates, as well as among the autotrophs. These questions can be resolved with information and samples taken during the PRPOOS cruise, and a more complete understanding of the character of the food web in the DCM can be developed. We look forward to this taking place.

\section{Microzooplankton}

Sampling for heterotrophic plankton of various size classes was extensive, but little of the information is yet available, especially when compared with the comprehensive study of Beers et al. (1982). We report here only a small fraction of the work, that from E. Swift's laboratory and based upon sampling with nets associated with his Seabird CTD-fluorometer-submarine light system. The discussion is limited to the relation of the observations to the DCM. The populations of protozoan microzooplankton in the euphotic zone were 
largely at depths above the DCM, suggesting the grazer assemblage may be organized with vertical structure along with the autotrophs. Tintinnids recorded here were most abundant at $90 \mathrm{~m}$ (Fig. 14) or above $60 \mathrm{~m}$ (Fig. 15). Primary production (Marra \& Heinemann in press) and bacterioplankton concentration were greatest above $60 \mathrm{~m} \mathrm{(B.} \mathrm{Cho} \mathrm{\&} \mathrm{F.} \mathrm{Azam,}$ Scripps Institution of Oceanography, pers. comm.). Some microzooplankton taxa achieved maximum concentrations in the DCM, such as Ascampbelliella (Fig. 15) and crustacean nauplii (Fig. 16). In both cases there were also high abundances elsewhere in the euphotic zone.

The Protoperidinia and other heterotrophic dinoflagellates were generally most abundant near the sea surface (Fig. 13), as found earlier by Beers et al. (1982). The 21-22 Aug cast also showed a secondary maximum of the $<20 \mu \mathrm{m}$ Protoperidinia in the DCM. These taxa were not highly correlated with chlorophyll concentration at the CLIMAX station, unlike their distribution in the North Atlantic subarctic front, the Irminger Sea (N. Atlantic, off Greenland) and the north wall of the Gulf Stream (Lessard 1984, E. Swift unpubl.). The ability of Protoperidinia to utilize bacteria and nanoplankton as food may determine their distributions and the maxima in bacteria and cyanobacteria were above the DCM in this study.

Acknowledgements. Several PRPOOS colleagues contributed directly to this paper: E. Renger, J. Downs, V. Fagerness, N. Hoepffner, J. Eppley, W. Biggley, P. Neidhardt, K. Heinemann. The PACODF CTD and nutrient data are due to the efforts of $B$ Willhoite, A. Hester, and R. Patrick. Capt. C. Johnson and his staff provided the wind data and much appreciated help of many kinds. G. Shor, SIO ship scheduling, assured that the cruise took place in spite of difficulties. We also thank R. C. Smith for the loan of equipment, D. Gifford for microzooplankton counts, and J. J. Cullen for a vigorous review. Supported by National Science Foundation grants OCE 83-15448, OCE 8405487, OCE 85-43072, OCE 83-8120842, and Office of Naval Research grant N00014-81-C-0062

\section{LITERATURE CITED}

Anderson, G. C. (1969). Subsurface chlorophyll maximum in the northeast Pacific Ocean. Limnol. Oceanogr. 14: 386-391

Beers, J. R., Reid, F. M. H., Stewart, G. L. (1975). Microplankton of the North Pacific Central Gyre. Population structure and abundance, June 1973. Int. Rev. ges. Hydrobiol. 60: $607-638$

Beers, J. R., Reid, F. M. H., Stewart, G. L. (1982). Seasonal abundance of the microplankton population in the North Pacific central gyre. Deep Sea Res. 29: 227-245

Bienfang, P. K., Szyper, J. P., Okamoto, M. Y., Noda, E. K. (1984). Temporal and spatial variability in a subtropical ecosystem. Limnol. Oceanogr 29:527-539

Coale, K. H., Bruland, K. W. (1987). Oceanic stratified euphotic zone as elucidated by ${ }^{234} \mathrm{Th}:{ }^{238} \mathrm{U}$ disequilibria. Limnol. Oceanogr. 32: 189-200
Craig, H., Hayward, T (1986). Oxygen supersaturation in the ocean: biological versus physical contributions. Science 235: $199-202$

Cullen, J. J. (1982). The deep chlorophyll maximum: comparing vertical profiles of chlorophyll a. Can. J. Fish. Aquat. Sci. 39: 791-803

Dandonneau, Y., Lemasson, L. (1987). Water-column chlorophyll in an oligotrophic environment: correction for the sampling depths and variations of the vertical structure of density, and observation of the growth period. J. Plankton Res. 9: 215-234

Dickey, T. D., Siegel, D. A., Bratkovich, A., Washburn, L. (1986). Optical features associated with thermohaline structures. SPIE (Soc. Photo-Optical Instrumentation Engineers) 637, Ocean Optics VIII: 308-312

Eppley, R. W. (1982). The PRPOOS program: a study of plankton rate processes in oligotrophic oceans. EOS (Trans. Am. Geophys. Un.) 63: 522

Eppley, R. W., Renger, E. H., Venrick, E. L., Mullin, M. M. (1973). A study of plankton dynamics and nutrient cycling in the central gyre of the North Pacific Ocean. Limnol. Oceanogr. 18: 534--551

Fasham, M. J. R., Platt, T., Irwin, B., Jones, K. (1985). Factors affecting the spatial pattern of the deep chlorophyll maximum in the region of the Azores front. Prog. Oceanogr. 14: $129-165$

Fitzwater, S. E., Knauer, G. A., Martin, J. H. (1982). Metal contamination and primary production: field and laboratory methods of control. Limnol. Oceanogr. 27: 544-551

Furuya, K., Marumo, R. (1983). The structure of the phytoplankton community in the subsurface chlorophyll maxima in the western North Pacific Ocean. J. Plankton Res. 5: 393-406

Garside, C. (1982). A chemiluminescent technique for the determination of nanomolar concentrations of nitrate and nitrite in seawater. Mar. Chem. 11: 159-167

Gieskes, W. W. C., Kraay, G. W. (1986). Floristic and physiological differences between the shallow and the deep nanophytoplankton community in the euphotic zone of the open tropical Atlantic by HPLC analysis of pigments. Mar. Biol. 91: 567-576

Glover, H. E., Smith, A. E., Shapiro, L. (1985). Diurnal variations in photosynthesis rates: comparisons of ultraphytoplankton with a larger phytoplankton size fraction. J. Plankton Res. 7: 519-535

Glover, H. E., Keller, M. D., Guillard, R. R. L. (1986). Light quality and oceanic ultraphytoplankters. Nature, Lond. 319: 142-143

Gordon, D. C., Jr (1971). Distribution and particulate organic carbon and nitrogen at an oceanic station in the central Pacific. Deep Sea Res. 18: 1127-1134

Haas, L. W. (1982). Improved epifluorescence microscopy for observing planktonic microorganisms. Annls inst. océanogr., Paris 58: 261-266

Hayward, T L. (1987). The nutrient distribution and primary production in the central North Pacific. Deep Sea Res. 34: $1593-1627$

Hayward, T L., Venrick, E. L., McGowan, J. A. (1983). Environmental heterogeneity and plankton community structure in the central North Pacific. J. mar. Res. 41: $711-729$

Herbland, A., Voituriez, B. (1979). Hydrological structure analysis for estimating the primary production in the tropical Atlantic Ocean. J. mar. Res. 37: 87-101

Holm-Hansen, O., Lorenzen, C. J., Holmes, R. W., Strickland, J. D. H. (1965). Fluorometric determination of chlorophyll. J. Cons. perm. int. Explor Mer 30: 3-15 
Ichikawa, T., Nishizawa, S. (1975). Particulate organic carbon and nitrogen in the eastern Pacific Ocean. Mar. Biol. 29: $129-138$

Jamart, B. M., Winter, D. F., Banse, K. (1979). Sensitivity analysis of a mathematical model of phytoplankton growth and nutrient distribution in the Pacific Ocean off the northwestern U.S. coast. J. Plankton Res. 1: 267-290

Jamart, B. M., Winter, D. F., Banse, K., Anderson, G. C., Lam, R. K. (1977). A theoretical study of phytoplankton growth and nutrient distribution in the Pacific Ocean off the northwestern U.S. coast. Deep Sea Res. 24: 753-773

Johnson, P. W., Sieburth, J. MCN. (1982). In situ morphology and occurrence of eucaryotic phototrophs of bacterial size in the picoplankton of estuaries and oceanic waters. J. Phycol. 18: 318-327

Kiefer, D. A., Olson, R. J., Holm-Hansen, O. (1976). Another look at the nitrite and chlorophyl maxima in the central North Pacific. Deep Sea Res. 23: 1199-1208

Knauer, G., Martin, J. H., Karl, D. M. (1984). The flux of particulate organic matter out of the euphotic zone. Global Ocean Flux Study. National Academy Press, Washington, D.C. p. $137-150$

Laws, E. A., DiTullio, G. R., Redalje, D. G. (1987). High phytoplankton growth and production rates in the North Pacific subtropical gyre. Limnol. Oceanogr. (in press)

Laws, E. A., Redalje, D. G., Haas, L. W., Bienfang, P. K., Eppley, R. W., Harrison, W. G., Karl, D. M., Marra, J. (1984). High phytoplankton growth and production rates in oligotrophic coastal waters. Limnol. Oceanogr. 29: 1161-1169

Le Bouteiller, A. (1986). Environmental control of nitrate and ammonium uptake by phytoplankton in the equatorial Atlantic Ocean. Mar. Ecol. Prog. Ser. 30: 167-179

Lessard, E. J. (1984). Oceanic heterotrophic dinoflagellates: distribution, abundance, and role as microzooplankton. Ph.D. dissertation, Univ. of Rhode Island

Mantoura, R. F. C., Llewellyn, C. A. (1983). The rapid determination of algal chlorophyll and carotenoid pigments and their breakdown products in natural waters by reversephase high-performance liquid chromatography. Analytica chim. Acta 151: 297-314

Marra, J., Heinemann, K. (in press). Primary production in the North Pacific Central Gyre. Deep Sea Res.

McGowan, J. A., Hayward, T L. (1978). Mixing and oceanic productivity. Deep Sea Res. 20: 51-68
Murphy, L. S., Haugen, E. M. (1985). The distribution and abundance of phototrophic ultraplankton in the North Atlantic. Limnol. Oceanogr. 30:47-58

Postma, H., Rommets, J. W (1979). Dissolved and particulate organic carbon in the North Equatorial Current of the Atlantic Ocean. Neth. J. Sea Res. 13: 85-98

Redalje, D. G., Laws, E. A. (1981). A new method for estimating phytoplankton growth rates and carbon biomass. Mar. Biol. 62: 73-79

SIO (1974). Data report. CLIMAX 1 Expedition. Scripps Institution of Oceanography. Ref. No. 74-20, p. 1-41

Sharp, J. H. (1974). Improved analysis for 'particulate' organic carbon and nitrogen from seawater. Limnol. Oceanogr. 19: 984-989

Sharp, J. H., Perry, M. J., Renger, E. H., Eppley, R. W. (1980). Phytoplankton rate processes in the oligotrophic waters of the central North Pacific Ocean. J. Plankton Res. 2: $335-353$

Simonot, J.-Y., Le Treut, H. (1986). A climatological field of mean optical properties of the world ocean. J. Geophys. Res. 91: 6642-6646

Taylor, A. H., Harris, J. R. W. Aiken, J. (1986). The interaction of physical and biological processes in a model of the vertical distribution of phytoplankton and stratification. In: Nihoul, J. (ed.) Marine interfaces hydrodynamics. Elsevier, Amsterdam, p. 313-330

Venrick, E. L. (1979). The lateral extent and characteristics of the North Pacific Central environment at 35N. Deep Sea Res. 26: 1153-1178

Venrick, E. L. (1982). Phytoplankton in an oligotrophic ocean: observations and questions. Ecol. Monogr. 52: $129-154$

Venrick, E. L., Hayward, T. L. (1984). Determining chlorophyll on the 1984 CalCOFI surveys. Calif. Coop. Oceanic Fish. Invest. Rep. 25: 74-79

Venrick, E. L., Cumming, S. L., Kemper, C. A. (in press a). Picoplankton and the resulting bias in chlorophyll retained by traditional glass-fiber filters. Deep Sea Res.

Venrick, E. L., McGowan, J. A., Cayan, S. E., Hayward, T. L. (in press b). Climate and chlorophyll a: long-term trends in the central North Pacific Ocean. Science

Venrick, E. L., McGowan, J. A., Mantyla, A. W. (1972). Deep maxima of photosynthetic chlorophyll in the Pacific Ocean. Fish. Bull. U.S. 71: 41-52 